\title{
Indigenous Intellectuals
}





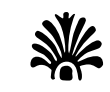

\title{
Indigenous Intellectuals
}

\author{
Knowledge, Power, \\ and Colonial Culture in
}

Mexico and the Andes

Gabriela Ramos and

Yanna Yannakakis, EDITORS

Duke University Press

DURHAM \& LONDON 2014

\section{标}




\section{(C) 2014 Duke University Press}

All rights reserved

Printed in the United States of America on acid-free paper @

Designed by Kristina Kachele

Typeset in Quadraat by Tseng Information Systems, Inc.

Library of Congress Cataloging-in-Publication Data

Indigenous intellectuals : knowledge, power, and colonial culture in Mexico and the Andes / Gabriela Ramos and Yanna Yannakakis, editors.

$$
\text { pages } \mathrm{cm}
$$

Includes bibliographical references and index.

ISBN 978-0-8223-5647-9 (cloth : alk. paper)

ISBN 978-o-8223-566o-8 (pbk. : alk. paper)

1. Indians of Mexico-Intellectual life. 2. Indians of Mexico-Civilization.

3. Indigenous peoples-Andes-Intellectual life. 4. Indigenous peoples-Andes-

Civilization. I. Ramos, Gabriela. II. Yannakakis, Yanna, 1967-

$$
\text { F1219.3.156I53 } 2014
$$

$305.80098-\mathrm{dc} 23$

2013045004 
For Nancy Farriss 
